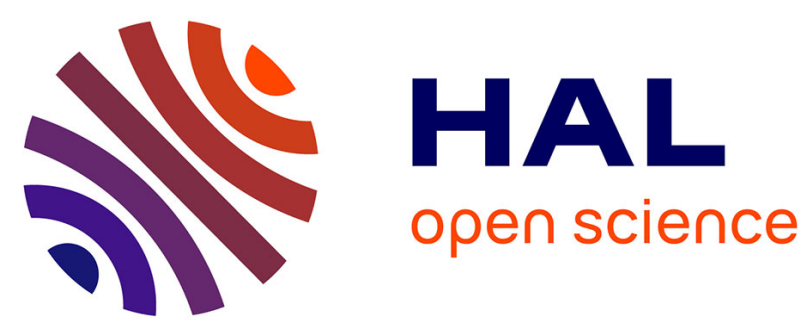

\title{
A Simulation model to evaluate the effect of cooperation between grain merchants in managing GM and non-GM segregation for maize
}

François Coléno, Mourad Hannachi

\section{- To cite this version:}

François Coléno, Mourad Hannachi. A Simulation model to evaluate the effect of cooperation between grain merchants in managing GM and non-GM segregation for maize. Food Control, 2015, 47, pp.6065. 10.1016/j.foodcont.2014.06.040 . hal-01198228

\section{HAL Id: hal-01198228 \\ https://hal.science/hal-01198228}

Submitted on 27 May 2020

HAL is a multi-disciplinary open access archive for the deposit and dissemination of scientific research documents, whether they are published or not. The documents may come from teaching and research institutions in France or abroad, or from public or private research centers.
L'archive ouverte pluridisciplinaire HAL, est destinée au dépôt et à la diffusion de documents scientifiques de niveau recherche, publiés ou non, émanant des établissements d'enseignement et de recherche français ou étrangers, des laboratoires publics ou privés. 


\title{
A simulation model to evaluate the effect of cooperation between grain merchants in managing GM and non-GM segregation for maize
}

\author{
F.C. Coléno*, M. Hannachi \\ INRA UMR 1048 SAD-APT, bâtiment EGER, BP1, 78850 Thiverval-Grignon Cedex, France
}

\section{A R T I C L E I N F O}

\section{Article history:}

Received 14 February 2014

Received in revised form

22 May 2014

Accepted 20 June 2014

Available online 2 July 2014

\section{Keywords:}

GM

Coexistence

Supply chain

Coopetition

\begin{abstract}
A B S T R A C T
GM and non-GM coexistence, as defined by the European commission, defines a product as non-GM if it contains less than $0.9 \%$ of GM material. To avoid the risk of mixing GM and non-GM in the supply chain it is recommended to separate the two flows with specialized infrastructure. But doing so it is not possible to separate all the product and it lead to an increase of the cost. Using a simulation model of supply chain management we show that if competing grain merchants cooperate by sharing their infrastructure it is possible to increase the quantity of GM and non-GM separated and to decrease the collection cost. Nevertheless such strategy will increase the transaction cost between competing companies.
\end{abstract}

() 2014 Elsevier Ltd. All rights reserved.

\section{Introduction}

The prospect of growing GM crops in Europe generated conflict between proponents and opponents of this technology (Levidow, Carr, \& Wield, 2000), leading at first to a moratorium on GM crops. This moratorium ended in 2004, when the regulation of coexistence between GM and non-GM crops in the landscape and segregation of the two product (GM and non GM) in the supply chain were set up:

- For the consumer's information the aim of these regulations is to guarantee that any food containing material that contains more than $0.9 \%$ of GM would be labelled "contains GM" (EC, 2003a).

- For the food industry the objective is to enable GM products to be traced throughout the supply chain ("from farm to fork") (EC, 2003b),

- Regarding agricultural production, this regulation concerns the release into the environment of GMO (EC, 2001) and so aims to avoid cross-pollination between GM and non-GM crops (EC, 2003c).

For agricultural production, this coexistence generates several problems. On a farm, use of the same agricultural machinery, such as a seed drill or harvester, for both GM and conventional

\footnotetext{
* Corresponding author

E-mail address: coleno@grignon.inra.fr (F.C. Coléno).
}

production, increases the risk of admixture (Jank, Rath, \& Gaugitsch, 2006). Moreover, a farmer using GM seed has to be sure that his fields will not contaminate the conventional production of his neighbours. This can be done in two ways. The first is to have an isolation distance between GM and non-GM fields (Byrne \& Fromherz, 2003; Squire, Lecomte, Hüsken, Soukup, \& Messéan, 2013) because maize pollen has a short dispersal range (Della Porta et al., 2008). The second is to ensure a time lag between the growth of GM and non-GM crops so that they do not flower simultaneously (Messan et al., 2006, 112 pp.).

For the industry, the problem is to guarantee the level of GM material in the product (Gryson et al., 2013). This is done using risk management policies such as HACCP (Scipioni, Saccarola, Arena, \& Alberto, 2005) or Failure Mode and Effect Analysis (Arvanitoyannis \& Savelides, 2007) combined with testing procedures using quantitative methods such as the PCR test (Arvanitoyannis, Choreftaki, \& Tserkezou, 2006; Lüthy, 1999; ).

For maize production, the link between industry and farms is the grain merchant, whose infrastructure is the site of the highest mixing risk between GM and non-GM corps (Le Bail \& Valceschini, 2004). Several critical features have been identified in this collection chain (Bullock \& Desquilbet, 2002; Le Bail, 2003), concerned with cropping plan management, storage of harvested products and, in the case of maize, drying, which is a bottleneck in maize collection. These critical points are linked with the fact that grain merchants have to combine the production of several dozen fields in their collection silos and maize dryers. Furthermore, the batches obtained must be dealt with in less than $48 \mathrm{~h}$ to protect the maize 
quality (Coléno, le Bail, \& Raveneau, 2005). It is thus not possible to exclude batches by using the PCR test, which takes more than $48 \mathrm{~h}$. Moreover, the large investment necessary for the implementation of two isolated collection chains means that the GM and non-GM products need to be segregated using the existing infrastructure. Two possible strategies have been identified to segregate the two products (Coléno et al., 2005; Le Bail, 2003; Miraglia et al., 2004). These strategies are based on:

- The separation of the two products in space, allocating one chain to each type of crop, so that each collection silo receives only one type of product. Dryers are also allocated to one type of product.

- The separation of the two products by the timing of their deliveries. In this case, each product is delivered to the nearest collection silo to the farm, but at a specific time. Thus, non-GM grain can be delivered in the beginning of the collection period and GM at the end. There is no risk of mixing between non-GM and GM, which might lead to downgrading of the non-GM crop.

Moreover, these strategies do not have the same effect on landscape organization and on the risk of cross-pollination between GM and non-GM fields. The spatial strategy could allocate parts of the landscape to each crop and thus minimize accidental GM presence, which is not possible with the temporal strategy (Coléno \& Angevin, 2013; Coléno, Angevin, \& Lécroart, 2009). Grain merchants have a key role in creating such homogeneous zones for GM and non-GM production. They can influence farmers' cultivar choices using production contracts and price differences between crops. But if there is more than one grain merchant operating in any given region they would have to cooperate to create a homogenous zone of sufficient size; otherwise it would not be big enough to ensure a sufficiently low threshold in the non-GM batches collected (Coléno et al., 2009).

Moreover, such cooperation between companies could improve the efficiency of segregation of the two products. In this paper we want to explore this hypothesis using a model of grain flow simulation in the collection process. After presenting the model, we will evaluate the different strategies using two criteria: the collection cost and the proportion of non-GM that is stored as non-GM at the end of the collection process.

\section{The GM and non-GM maize collection chain}

Maize collection in Europe occurs in autumn - generally from September to December. During this period, farmers harvest their maize and deliver it to the collection silos of the firm purchasing their harvest. Each of these silos is made up of different cells, all of the same size. The cells are small compared to the quantity of maize collected. Very often, maize is transferred from collection silos to dryers. When maize is dried, it is stored in uniform batches in storage silos in seaports or railway stations. These storage silos may contain 300000 tons or more. To ensure a high quality of maize, and hence access to the best food markets, the maximum time from harvesting to drying should be less than $48 \mathrm{~h}$. To ensure GM and non-GM segregation in the collection chain, several factors have been shown to be important (Coléno et al., 2005; Le Bail, 2003):

- Mixing of products can occur in the collection silos. When all the cells contain maize the silo manager has to choose between (i) accepting farmers' deliveries and thus mixing the two products or (ii) refusing some deliveries to avoid mixing but with the risk that the farmer will sell his crop to another firm. The type of relationship between the firm and the farmer, and whether there is another grain merchant in the vicinity will influence the silo manager's decision.
- Mixing may also occur in the dryers. To reduce drying costs, dryers are used at their full capacity. In so doing, mixing may occur if there is not enough of one product. Moreover, to avoid contamination between products in the dryer, the first batch of non-GM that follows a GM lot must be sold as GM.

\section{Presentation of the model (Coléno, 2008)}

The model deals with these two critical points and takes into account transport between collection silos and dryers. It is therefore made up of three modules: collection silos, dryers and transport. All the variables used in the model are presented in Table 1.

In order to take into account the decentralized method we will consider two scheduling of collections from silos and dryers. The first one, in favour of segregation, consists of making uniform batches, while the second focuses on cost minimization using the total storage and drying capacity.

\subsection{Collection silos}

The collection silo model is shown in Fig. 1. Each day, a collection silo receives a quantity of each product, $D_{t, p}$, where $p$ is the kind of product (GM or non-GM) and $t$ the time period. The delivery is then put into cells $\left(C_{i}\right)$ that contain the same product or are empty. If there is a residue when all the cells have been checked, its management depends on the silo's management strategy:

- In the case of scheduling in favour of segregation (SS1) the residue will be refused and deferred to the next day. So $D_{t+1, p}=D_{t+1, p}+D_{t, p}$.

- In the case of scheduling in favour of quantity maximization (SS2), the residue will be put in the first cell with sufficient free space. The maize in this cell will then be considered as GM.

\subsection{Transport}

Each day, the collection silos can call for transport if their stock is above a certain threshold $(T)$ :

If $C_{\mathrm{i}} \geq \mathrm{T}$ then ask for transport.

These requests are treated using the First In First Out management rule, the older batch being given priority. To take into account the time constraint of $48 \mathrm{~h}$ for the food market, the delivery stored at $t-1$ has the higher priority level. If it is not possible to store the incoming batch in the waiting silos at the drying facility, the delivery is deferred to the next day.

\subsection{Dryers}

Drying facilities consist of two structures: dryer waiting silos, where maize is stored before being dried, and the actual dryers.

\section{Table 1}

Signification of the variable used for the model (for more information about the model see Coléno, 2008).

\begin{tabular}{ll}
\hline Variable & Signification \\
\hline$D_{t, p}$ & Quantity receive of product $p$ by a collection silo at time $t$ \\
$C_{i}$ & Available capacity of the cell $i$ (each silo contains 4 cells). \\
$C_{\max }$ & Minimum capacity of a cell \\
$\mathrm{DT}_{t}$ & Type of maize dried in day $t$ \\
$\mathrm{WQ}_{\mathrm{GM}, t}$ & Quantity of GM maize that is waiting for being dried at day $t$ \\
$\mathrm{WQ}_{\mathrm{nonGM}, t}$ & Quantity of non GM maize that is waiting for being dried at day $t$ \\
$\mathrm{DC}$ & Drying capacity of a dryer for each day \\
$\mathrm{S}_{\mathrm{GM}, t}$ & Stock of dried GM maize at the end of day t \\
$\mathrm{S}_{\mathrm{nonGM}, t}$ & Stock of dried non GM maize at the end of day t \\
\hline
\end{tabular}




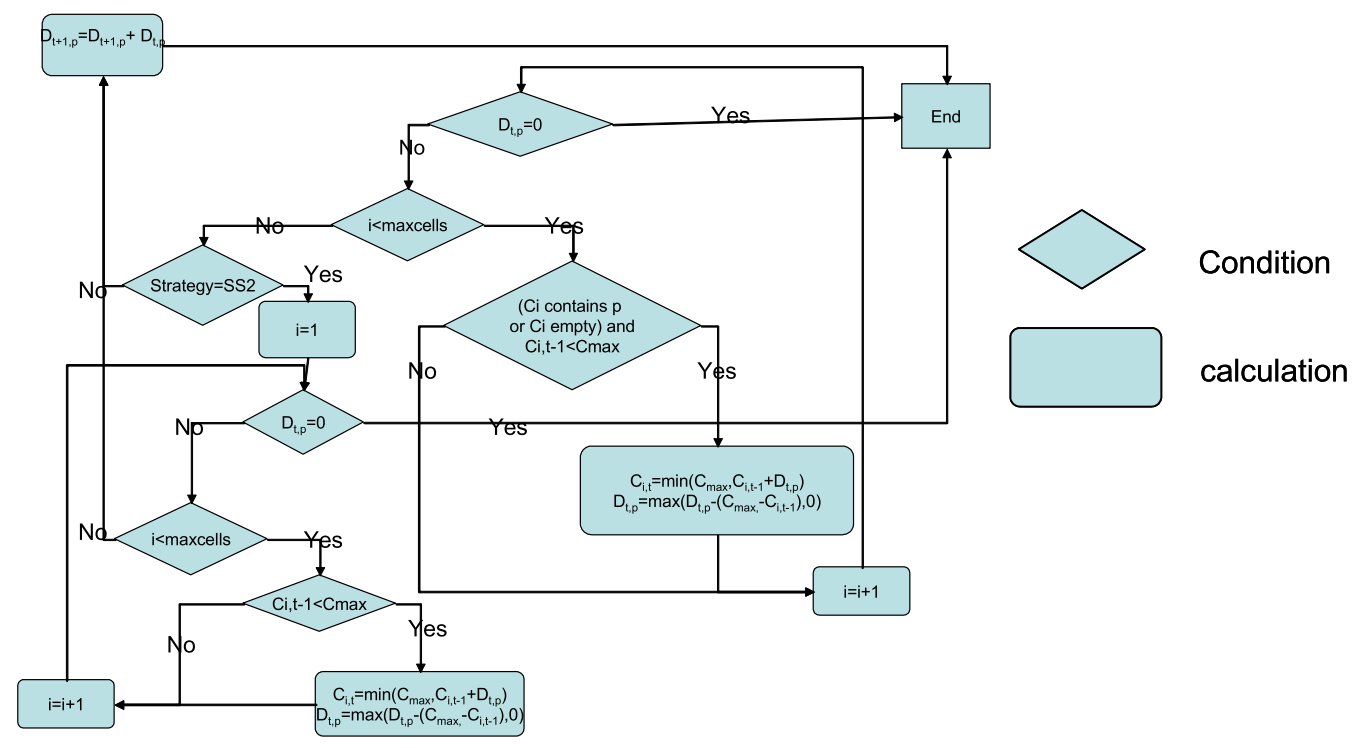

Fig. 1. The collection silo model (Coléno, 2008).

Each day, a dryer dries one batch of maize. Changing the type of product dried $\left(\mathrm{DT}_{t}\right)$ from one day to another can cause a loss (the first batch of non-GM following a GM batch is considered as GM). So the model tries first to minimize these changes. Each day the dryer has a waiting quantity $\left(\mathrm{WQ}_{t}\right)$ of GM and non-GM to dry.

In the case of the strategy in favour of segregation (SD1) the model works as shown in Fig. 2. The model will try to dry a batch of the same product that was dried in the previous period, even if it is not possible to use the dryer at its full capacity (DC). In the case of the strategy in favour of cost minimization (SD2) the model works as shown in Fig. 3. The model will try to use the dryer at its full capacity over each period, even if this causes a change in the type of product dried or a mixing of the two products.

\subsection{Variables used for simulation}

The model runs with a daily time step. Each day, collection silo stocks are calculated, taking into account the GM and non-GM deliveries. GM and non-GM quantities dried are calculated, taking into account the waiting stock at the drying facility. From these new values of stocks in collection silos and dryer waiting silos, transport of maize from collection silos to drying facilities is calculated.

We first simulated the collection with only one product collected in order to compare the cost of a situation with segregation with the present situation (without segregation). We then made simulations for the case of segregation between GM and nonGM crops. In this case, we considered three distributions of GM and non-GM products in the deliveries (GM representing 75, 66 and $50 \%$ of the total deliveries). For each of these situations we made a

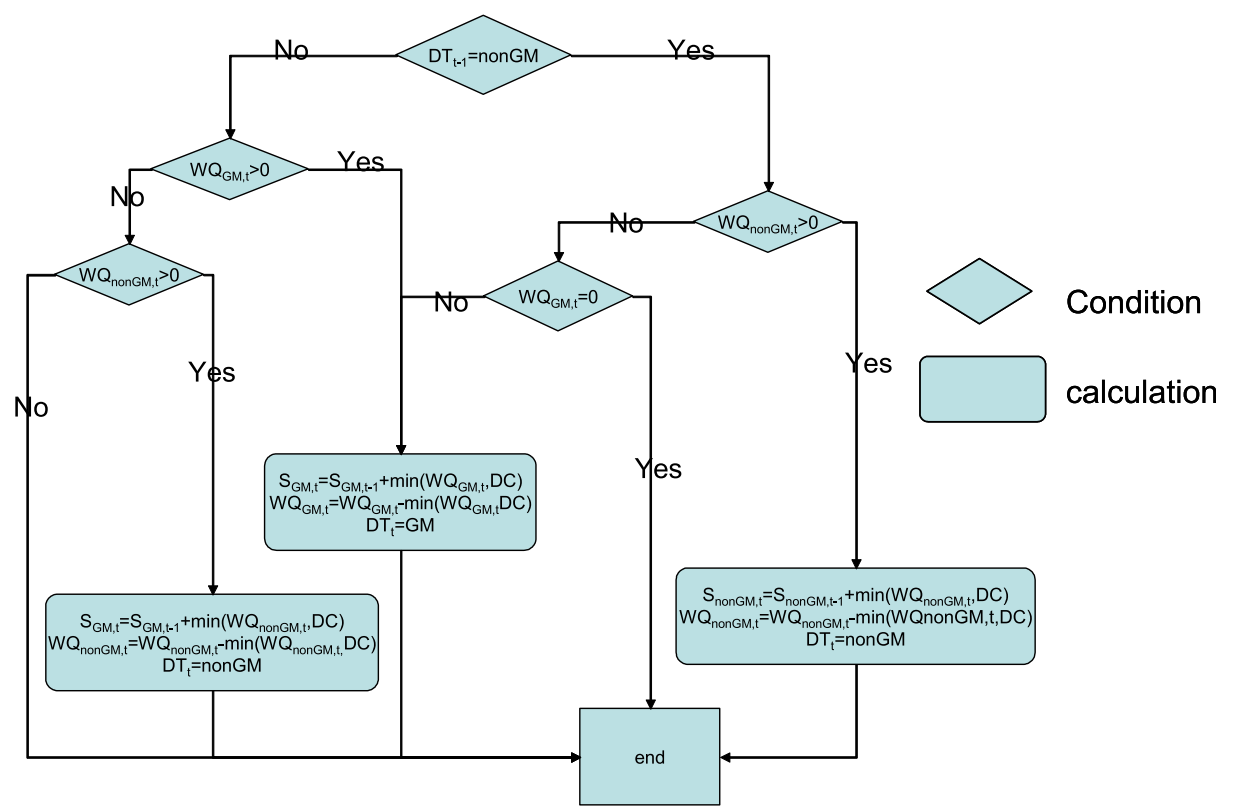

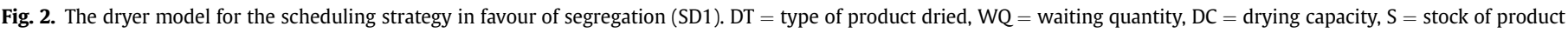
dried (Coléno, 2008). 


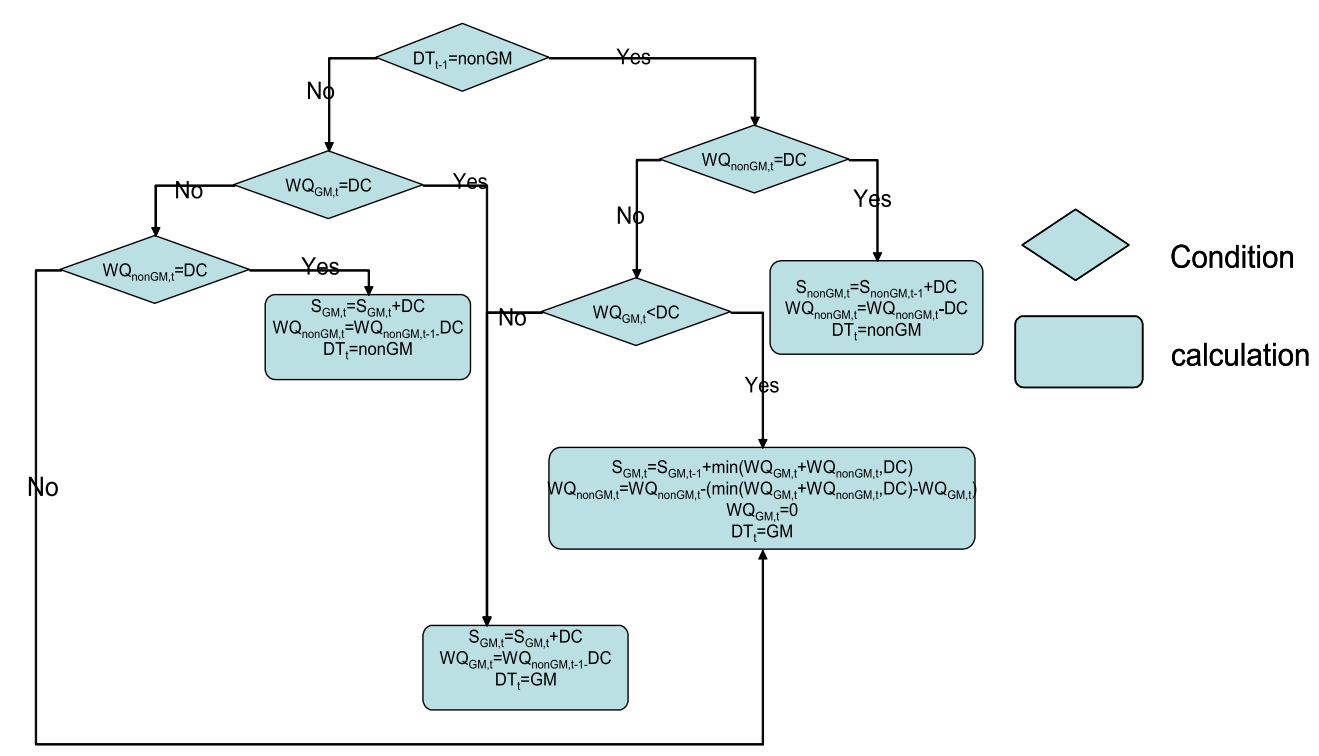

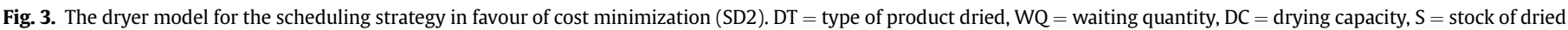
product (Coléno, 2008).

simulation with 5 different distances between silos and dryers. In order to estimate the value of cooperation between competing cooperatives we considered a landscape with 25 collecting silos and 5 dryers managed by two cooperatives. Three hypotheses of distribution of dryers and silos were considered:

- The two companies manage all the silos and dryers cooperatively.

- One company owns 4 dryers and 20 silos and the other one owns one dryer and 5 silos. The companies manage their silos and dryers without cooperation.

- One company owns 3 dryers and 15 silos and the other one owns 2 dryers and 10 silos. They don't cooperate in the management of the grain collection.

When the companies own more than one dryer we assumed that they adopt a spatial management of the collection (Coléno, 2008; Miraglia et al., 2004). This management is the one mostly used by French companies in order to take into account how the landscape is split up (Hannachi, 2011, ). When there is only one dryer we considered a management strategy where the two products are taken into the silos and flow management is used try to get homogenous batches (Coléno, 2008).

Taking into account all these hypotheses we made 75 different simulations.

For each of these simulations we compared the quantity of each product (GM and non-GM) at the end of the process to the quantity of the product delivered. To do so we calculated the ratio between these two values. The ratio of GM can therefore be higher than $100 \%$ if there is non-GM crop mixed with GM. To consider the cost we compared (i) the increase in transport cost compared with the situation with one product and (ii) the rate of dryer use, which is a good indicator of drying cost, as this cost is almost independent of the quantity dried.

\section{Results}

Fig. 4 shows the level of non-GM grain that the companies are able to separate.

We can see that cooperation is the most efficient strategy in every case. In the cases where there is 66 or $75 \%$ of GM grain in the collection it is possible to separate $100 \%$ of the non-GM grain, but when there is $50 \%$ of GM grain, the level of separation is lower. This is because the number of dryers allocated to non-GM by each company is insufficient for the quantity of grain delivered by farmers. The companies are thus unable to manage all the non-GM batches during the collection.

When the companies do not cooperate the efficiency of the collection management depends on the numbers of dryers owned by the two companies. Thus, in the case where the companies own 2 or 3 dryers the efficiency of the non-GM collection is the same as when the companies cooperate. But when one company owns only one dryer there is only $60 \%$ of the non-GM grain separated in the collection process. This is because with one dryer the company is not able to segregate the non-GM batches and mix them with the GM batches.

Fig. 5 shows the quantity of GM grain at the end of the process compared to the quantity of GM grain delivered by farmers. When there is cooperation between the companies, the quantity of GM grain segregated is between 80 and $90 \%$ of the GM grain delivered by farmers. The fact that all the GM batches are not in the stock of the companies at the end of the process is linked to the low capacity of the infrastructure dedicated to GM grain. This is because the management strategies tested give priority to non-GM grain because of its greater value. When the companies don't cooperate the result depends on the distribution of the infrastructure. When

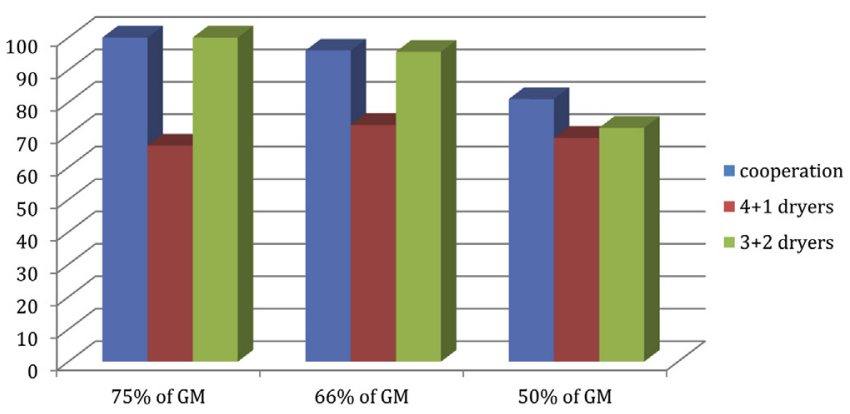

Fig. 4. Percentage of non-GM product at the end of the process compared to non-GM product delivered to grain merchants. 


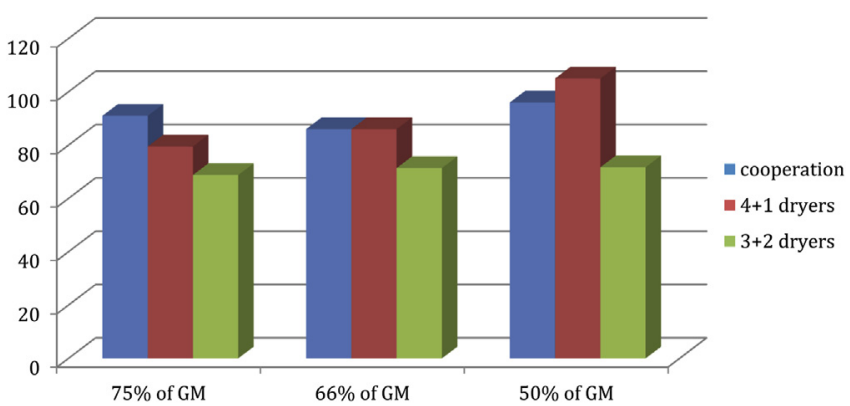

Fig. 5. Percentage of GM at the end of the process compared to GM product delivered to grain merchants.

one company owns only one dryer the proportion of GM at the end of the process is greater. This is because in this case the company is not able to use spatial segregation and so takes all the grain (GM and non GM) into the same silos and dryers. The two products are thus mixed and sold as GM. The high proportion of GM grain is therefore linked to a low proportion of non-GM. When the companies have 2 or 3 dryers, the level of GM at the end of process is lower, even compared to the situation when the companies cooperate. This is due to the arrangement of the infrastructure in favour of the non-GM grain. As each of the companies has the same strategy, the number of dryers allocated to GM grain is lower than when they cooperate. The dryers allocated to GM grain are thus under-used, as the ones dedicated to non-GM grain are used to overcapacity.

Fig. 6 compares the quantity of grain (GM and non-GM) at the end of the process with that delivered by farmers. For all types of organization, segregation leads to a loss in the quantity of grain collected and dried, as the companies are not able to dry all the grain delivered by farmers. Nevertheless, the cooperation strategy is the most efficient as nearly $90 \%$ of the grain delivered by farmers is collected. On the other hand in the two other cases there is only $70-85 \%$ of the grain collected (depending on the proportion of GM grain). Moreover, when the companies don't cooperate, the quantity of grain collected is higher in the case where one company owns 4 dryers and the other only one. This is because the company which has only one dryer collects all the grain, mixing GM and nonGM, so being able to use all its drying capacity, while the other company can't use all its drying capacity. The drying capacity of this company is dedicated to dry only one product. Using it to dry another product at the same time leads to inefficient use.

Fig. 7 shows the transport cost due to segregation for the 3 strategies and the one when there is no segregation. We can see that whatever the strategy chosen the transportation cost is higher when there is segregation than when there is only one product to

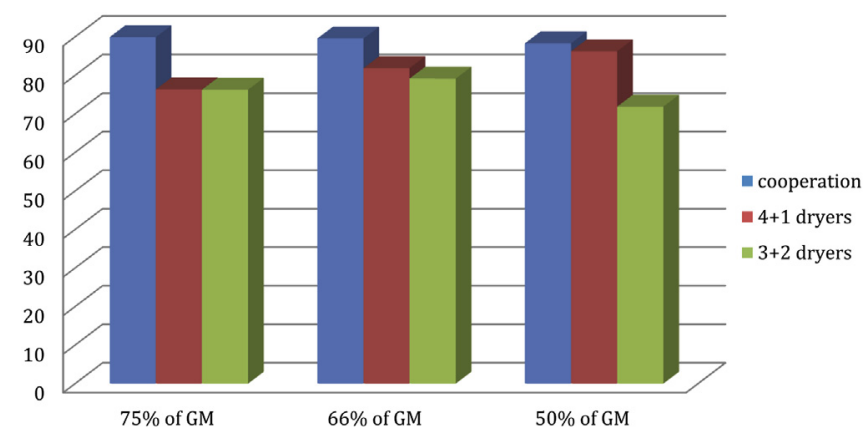

Fig. 6. Total grain at the end of the process compared to the total grain delivered to grain merchants.

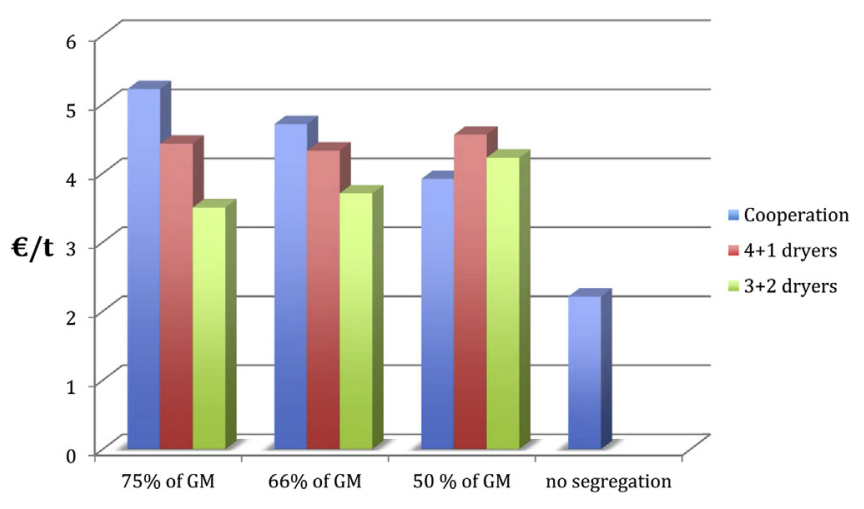

Fig. 7. Average cost for the 3 strategies and with no segregation.

collect. We then can see that the transportation cost is lower when the companies work together. In this case the companies can minimize the distance between silos and dryers for all the 25 silos and 5 dryers. On the other hand, when there is no cooperation between the companies it is not possible to do so. The company can only try to find a local optimum, taking into account their own infrastructure. This is less efficient than when both companies cooperate. Moreover, comparing Figs. 6 and 7 we can see that the transport cost is linked to quantity of grain collected. This explains why the transport cost in the case where one company owns 3 dryers and the other 2 is higher than when there is 50\% of GM grain. In this case it is the distribution that allows more grain to be collected.

\section{Discussion}

The implementation of such a cooperation strategy between rival companies requires an information system allowing the various companies to know exactly the quantities of products stored in their name in their competitors' silos. This information system has to ensure confidentiality of the strategic data of companies. The management of this information thus requires a third party which has the confidence of all the companies and which is able to ensure, at a given moment, the collection and sharing of the information needed by all the companies (Hannachi \& Coléno, 2012). The question of the importance of such an information system and the difficulties of its implementation has already been investigated in other agricultural fields, specifically for high-value products with a high level of competition, such as champagne (Soler \& Tanguy, 1998). In the case of GM/non-GM coexistence, management certification companies and supply chain managers have the necessary knowledge to fulfil such a role (Fliedner, 2003) and have shown that they already have the confidence of the various companies in situations other than harvest management.

The coordination between grain merchants for the choice of the specialized production zones (Coléno et al., 2009) and for the management of the harvest collection creates new costs. This increase in the transaction costs will increase the cost of coexistence between GM and non-GM products. Moreover, such a management strategy will lead to a centralization of the collection planning for the whole supply chain: decision rules are imposed on each member of the supply chain (the place of delivery for farmers and trucks and the type of product to be handled for the silo and dryer managers). Such a strategy leads to an increase in the costs for each of the cost centres, as they cannot make rules to reduce them. There is therefore no scope for flexibility in the process, which leads to a big cost increase (Bullock \& Desquilbet, 2002). 


\section{Conclusion}

We have shown that to overcome difficulties in co-existence between GM and non-GM production at the collection level, it is necessary to plan the collection before it is due in order to specialize the infrastructure for one or the other product. Moreover we have shown that, at a territory level, the collection is more efficient when the grain merchants collaborate to decide where they will collect the GM and the non-GM grain. Nevertheless, even when grain merchant cooperate there is an increase of the collection cost. Moreover cooperation between competitors increases the transaction cost, for example because there is a need of an information system to know which quantity of grain belong to each of the companies. It is so necessary to make a trade of between:

- a cooperation strategy that increase the quantity of grain segregated, and so the value created, but that will increase the cost;

- a competing strategy that would avoid transaction cost but lead to less grain segregated, and so less value created.

Such trade off has to be made taking into account the price of GM and non-GM grain. Moreover, such collection strategies lead to the possibility of stricter collection territory governance, as considered by Byrne and Fromherz (2003). It would not be possible to introduce such collection strategies without consultation with the farmers; otherwise there is a risk that farmers will change their relationships with grain merchants and sell their harvest to the one with the fewest restrictions. These different types of governance should be evaluated, taking into account the cost to the farmers and for the grain merchant, together with the proportion of maize segregated.

\section{References}

Arvanitoyannis, I. S., Choreftaki, S., \& Tserkezou, P. (2006). Presentation and comments on EU legislation related to food industries-environment interactions: sustainable development, and protection of nature biodiversity-genetically modified organisms. International Journal of Food Science and Technology, 41, $813-832$.

Arvanitoyannis, I. S., \& Savelides, S. C. (2007). Application of failure mode and effect analysis and cause and effect analysis and Pareto diagram in conjunction with HACCP to a chocolate-producing industry: a case study of tentative GMO detection at pilot plant scale. International Journal of Food Science and Technology, 42, 1424-1442.

Bullock, D. S., \& Desquilbet, M. (2002). The economics of non-GMO segregation and identity preservation. Food Policy, 27, 81-99.

Byrne, P. F., \& Fromherz, S. (2003). Can GM and non-GM crops coexist? Setting a precedent in Boulder County, Colorado, USA. Journal of Food, Agriculture \& Environment, 1(2), 258-261.

Coléno, F. C. (2008). Simulation and evaluation of GM and non-GM segregation management strategies among European grain merchants. Journal of Food Engineering, 88, 306-314.

Coléno, F. C., \& Angevin, F. (2013). Evaluation of collection strategies for landscape and product flow management. In Y. Bertheau (Ed.), Genetically modified and non-genetically modified food supply chain (pp. 127-139). Chichester: WileyBlackwell.

Coléno, F. C., Angevin, F., \& Lécroart, B. (2009). A model to evaluate the consequences of GM and non-GM segregation scenarios on GM crop placement in the landscape and cross-pollination risk management. Agricultural Systems, 101, 49-56.

Coléno, F. C., le Bail, M., \& Raveneau, A. (2005). Segregation of GM and non-GM production at the primary production level. In A. Messan (Ed.), proceeding of the Second International Conference on Co-existence between GM and non-GM based agricultural supply chain (pp. 169-172). Montpellier (FRA): Agropolis Production, 14-15/11/2005.

Della Porta, G., Ederle, D., Bucchini, L., Prandi, M., Verderio, A., \& Pozzi, C. (2008). Maize pollen mediated gene flow in the Po valley (Italy): source-recipient distance and effect of flowering time. European Journal of Agronomy, 28, $255-265$.

European Commission. (2001). Directive 2001/18/EC of the European Parliament and of the Council of 12 March 2001 on the deliberate release into the environment of genetically modified organisms and repealing Council Directive 90/ 220/EEC - Commission Declaration. Official Journal of the European Union, L 106, $1-39,17.4 .2001$

European Commission. (2003a). Commission recommendations of 23 July 2003 on guidelines for the development of national strategies and best practices to ensure the coexistence of genetically modified crops with conventional and organic farming, 2003/556/EC 2624), 29/07/2003. Official Journal of the European Union, 46, L189, 36-47 (notified under document number A (2003).

European Commission. (2003b). Regulation (EC) $N^{\circ} 1829 / 2003$ of the European Parliament and of the Council of 22 September 03 concerning the traceability and labelling of genetically modified organisms and the traceability of food and feed products produced from genetically modified organisms and amending Directive 2001/18/EC. Official Journal of the European Union, 46, L268, 1-23, 18/ $10 / 2003$.

European Commission. (2003c). Regulation (EC) $N^{\circ} 1830 / 2003$ of the European Parliament and of the Council of 22 September 03 concerning the traceability and labelling of genetically modified organisms and the traceability of food and feed products produced from genetically modified organisms and amending Directive 2001/18/EC. Official Journal of the European Union, 46, L268, 24-28, 18/ $10 / 2003$.

Fliedner, G. (2003). CPFR: an emerging supply chain tool. Industrial Management \& Data Systems, 103, 14-21.

Gryson, N., Eeckhout, M., Messéan, A., Soler, L. G., Lécroart, B., Trouiller, A., et al. (2013). Empirical analysis of co-existence in commodity supply chains. In Y. Bertheau (Ed.), Genetically modified and non-genetically modified food supply chain (pp. 121-160). Chichester: Wiley-Blackwell.

Hannachi, M. (2011). La ccopétiotn au service du bien commun. Les stratégies des entreprises de collecte et de stockage de céréales face aux OGM (Phd thesis). Université Versailles Saint-Quentin-En-Yvelines.

Hannachi, M., \& Coléno, F. C. (2012). How to adequately balance between competition and cooperation? A typology of horizontal coopetition. International Journal of Entrepreneurship and Small Business, 17(3), 273-289.

Jank, B., Rath, J., \& Gaugitsch, H. (2006). Co-existence of agricultural production systems. Trends in Biotechnology, 24(5), 198-200.

Le Bail, M. (2003). GMO/non-GMO segregation in the supply zone of country elevators. In Proceeding of the first Conference on the co-existence of Genetically Modified Crops with Conventional and Organic Crops, Borupsgarrd (DNK), 13-14/ 11/2003 (pp. 125-127)

Le Bail, M., \& Valceschini, E. (2004). Efficacité et organisation de la séparation OGM/non OGM. Economie et Société. Série «systèmes agroalimentaires», 12(4), $18-29$.

Levidow, L., Carr, S., \& Wield, D. (2000). Genetically modified crops in the European Union: regulatory conflicts as precautionary opportunities. Journal of Risk Research, 3(3), 189-208.

Lüthy, J. (1999). Detection strategies for food authenticity and genetically modified foods. Food Control, 10, 259-361.

Messéan, A., Angevin, F., Gómez-Barbero, M., Menrad, K., \& Rodríguez-Cerezo, E. (2006). New case studies on the coexistence of GM and non-GM crops in European agriculture. Technical Report Series of the Joint Research Center of the European Commission, EUR 22102 En.

Miraglia, M., Berdal, K. G., Brera, C., Corbisier, P., Holst-Jensen, A., Kok, E. J., et al. (2004). Detection and traceability of genetically modified organisms in the food production chain. Food and Chemical Toxicology, 42, 1157-1180.

Scipioni, A., Saccarola, G., Arena, F., \& Alberto, S. (2005). Strategies to assure the absence of GMO in food products application process in a confectionery firm. Food Control, 16, 569-578.

Soler, L. G., \& Tanguy, H. (1998). Coordination between production and commercial planning: organisational and modelling issues. International Transactions in Operational Research, 5(3), 171-188.

Squire, G. R. Lecomte, J., Hüsken, A., Soukup, J., \& Messéan, A. (2013). Contribution of pollen and seed to impurity in crops. A comparison of maize, oilseed rape and Beet. In Y. Bertheau (Ed.), Genetically modified and non-genetically modified food supply chain (pp. 23-34). Chichester: Wiley-Blackwell. 